\title{
Lithic Industry of the Itomiura Site in the Lower Angara Region (Neolithic and Bronze Ages): Spatial Organization and Key Characteristics
}

\author{
Dmitry A. Gurulev, Liliya A. Maksimovich, \\ Polina O. Senotrusova and Pavel V. Mandryka* \\ Siberian Federal University \\ Krasnoyarsk, Russian Federation
}

Received 09.10.2019, received in revised form 27.02.2020, accepted 27.04.2020

\begin{abstract}
The article presents the results of the analysis of the collection of the Itomiura site located in the Lower Angara region. As for today, no markers or concepts of stone industry dynamics in the Neolithic and Bronze Age have been described for the territory of the Lower Angara region. The materials of the Itomiura site allow us to define some of these concepts. Based on the spatial distribution of findings in the cultural layer of the site, we identified 12 areas of concentration of stone pieces (clusters). The areas differ in their composition and types of economic and production activities held. Knapping areas with large amounts of debitage, unfinished items and used microcores predominate. There are also areas that are likely to be more associated with the use of stone tools and their rejuvenating. The combined occurrence of stone pieces with pottery fragments made it possible to distinguish several cultural and chronological complexes. The most clearly identifiable complexes are one with net-impressed pottery, previously dated to the late - final Neolithic period $\left(4^{\text {th }}-\right.$ first half of the $3^{\text {rd }}$ millennium $\left.B C\right)$, and another with "pearl-ribbed" pottery of the Bronze Age ( $2^{\text {nd }}$ millennium BC). The Neolithic complex is characterized by the use of various siliceous raw materials. The Bronze Age complex is marked by a wide use of purple-burgundy sedimentary rocks, the specificity of the industry in this period is also created by a series of bifacial items and thinned preforms. Stone industries of both assemblages include a variety of expedient flake tools and microblade production products, represented by different prismatic and edge-faceted cores. The data obtained, with their further correlation with the materials of other sites, can be used for the further study of stone industries of the Lower Angara region and the development of the concept of regional paleocultural dynamics.
\end{abstract}

Keywords: Middle Siberia, Lower Angara region, Neolithic, Bronze Age, lithic industry, stone raw material, spatial analysis, net-impressed pottery, pearl-ribbed pottery.

\footnotetext{
(C) Siberian Federal University. All rights reserved

* Corresponding author E-mail address: pepel-1s@mail.ru ORCID: 0000-0002-8647-3823 (Mandryka); 0000-0002-6992-3183 (Gurulev); 0000-0003-3969-9907 (Senotrusova); 0000-0002-5499-6996 (Maksimovich)
} 
The reported study was funded by Russian Foundation for Basic Research, Government of Krasnoyarsk Territory, Krasnoyarsk Region Science and Technology Support Fund, the research project No. 16-11-24005.

Research area: archaeology.

Citation: Gurulev, D.A., Maksimovich, L.A., Senotrusova, P.O., Mandryka, P.V. (2020). Lithic industry of the Itomiura site in the Lower Angara region (Neolithic and Bronze Ages): spatial organization and key characteristics. J. Sib. Fed. Univ. Humanit. Soc. Sci., 14(1), 17-30. DOI: 10.17516/1997-1370-0568.

\section{Introduction}

Despite large-scale and long-term studies of the cultures of the hunters and gatherers who inhabited the Lower (Nizhnyaya) Angara region in the Holocene, neither basic cultural and chronological scheme nor concepts of the development of stone industries have been formulated so far. The main reason for this was the small number of closed association type objects on widespread archaeological sites with mixed (compressed) deposits of different materials in one cultural layer. The mixed character of dissimilar materials led to the formation of a generalized image of the stone industry which existed throughout the Neolithic and Bronze Age and was homogeneous in its technological and typological features.

The separation of materials of different cultural and chronological complexes can be implemented when researchers apply the method of horizontal stratigraphy. It can be used in such conditions, when the cultural layer is excavated in large-scale horizontal exposures, but archaeological material is little and presented in the form of clusters from settlements which were inhabited for a short period. As for the Lower Angara region, this concerns the cultural strata far from the River Angara and the settlements located on the banks of small tributaries of the Angara (Berdnikova et al., 2014: 158; Vybornov, Tsybankov, Makulov, 2015: 48-49; Mandryka, 2018). Clusters of artifacts, identified in the structure of such a cultural layer, can be conventionally considered closed complexes, which mark various episodes in the life of this place when it was inhabited.

The purpose of this work is to elicit the technological, raw material and morphological features of the stone industries of the cultural and chronological complexes of the Itomiura ancient settlement. The article continues the previous research on the analysis of the findings from this archaeological site (Mandryka, Senotrusova, 2014; Senotrusova, Mandryka, 2018).

\section{Materials and methods}

The Itomiura ancient settlement is situated on the right bank of the River Mura (the left-bank tributary of the River Angara) $36 \mathrm{~km}$ higher than its mouth. The site was excavated in 2011-2012 by archaeological expedition from the Siberian Federal University. Reconnaissance work in the settlement helped to reveal two sectors of the cultural layer position. The first is located on the brow part of the first terrace above floodplain of the Mura River. The second sector is in 50-220 $\mathrm{m}$ from the river, on the second and third terraces above floodplain separated by a barely discernible scarp. We had two excavations to explore the north-western part of the site on the area of more than 13,500 $\mathrm{m}^{2}$ (Mandryka, Senotrusova, 2014, see Fig. 1).

Two cultural layers have been studied on the first terrace above floodplain (excavation No. 1 with an area of $1,254 \mathrm{~m}^{2}$ ). Stone pieces here are represented by a few findings which did not make up any informative complexes and are not covered in this work.

The next study zones were slopes and surfaces of the second and third terraces with a total area of $12,400 \mathrm{~m}^{2}$ in excavation No. 2. We found one cultural layer at a depth of 0.1-0.3 m, which corresponds to the soil horizons of the lying under the turf dark-grey sandy loam and brown sand. Artifacts spatial organization showed that in the structure of 


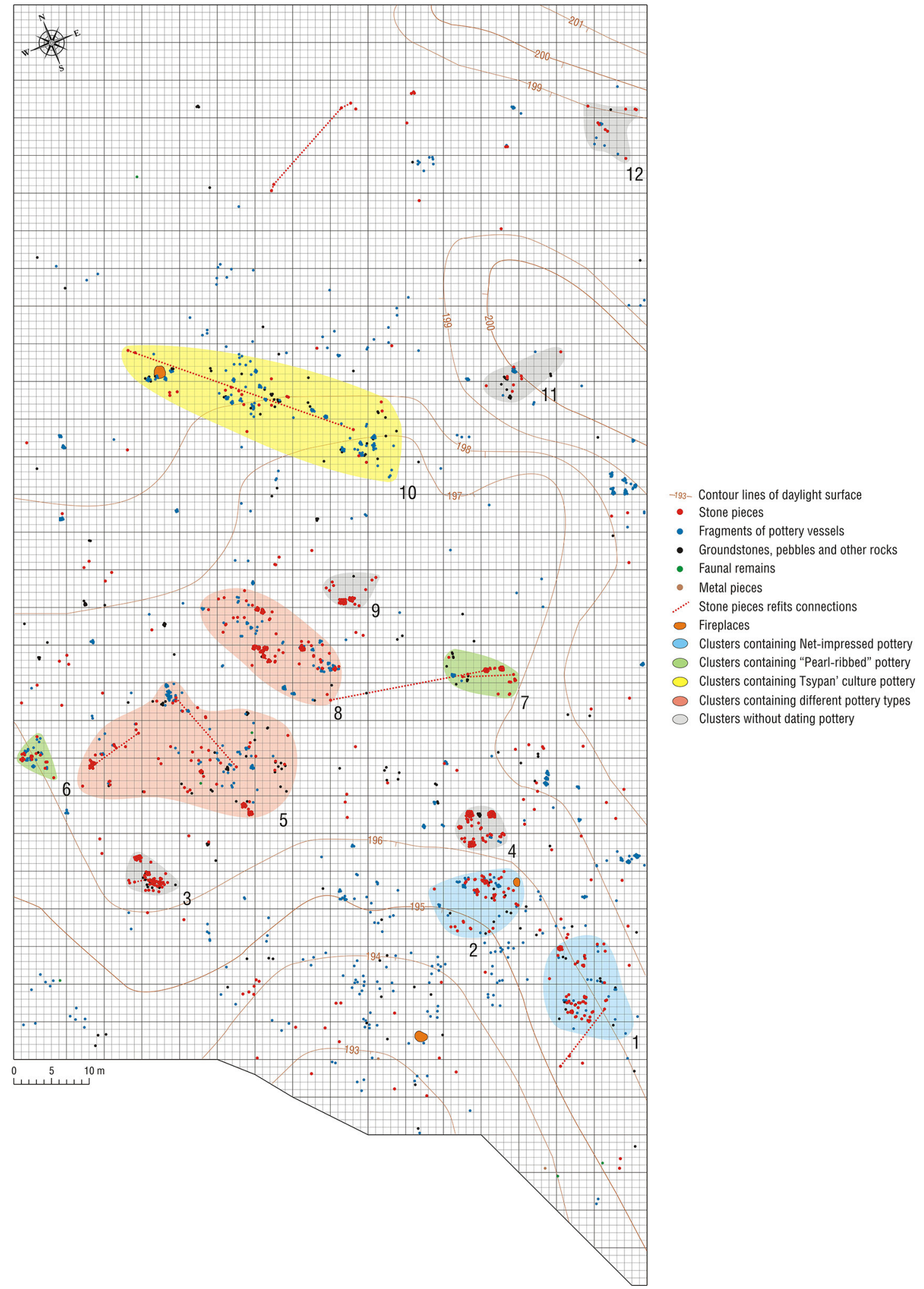

Fig. 1. Spatial organization of the cultural layer of the site Itomiura (excavation No. 2) 


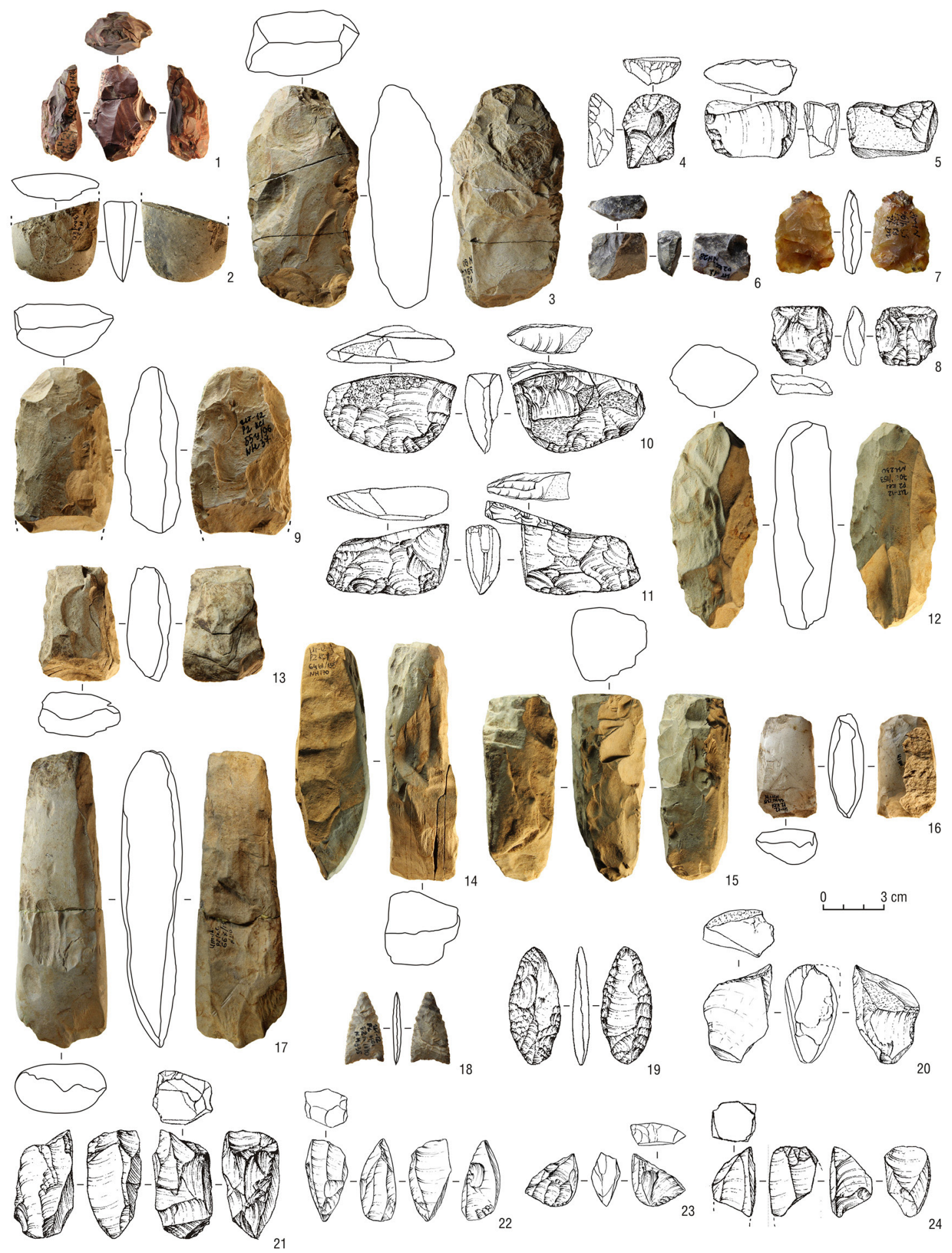

Fig. 2. Lithic industry of the site Itomiura (excavation No. 2): 1-4 - cluster 1; 5-9 - cluster 2; 10-11 - cluster 3; 12-19 - cluster 5; 20-24 - cluster 6. 1, 5, 6, 11, 20-24 - microcores;

2, 9, 15 - chopping tool fragments; 3, 12-14 - unfinished chopping tools; 4 - end-scraper; 7 - bifacial item; 8 - chisel-like tool; 10 - precore; 16-17 - chopping tools; 18, 19 - arrowheads 
the cultural layer there can be identified 12 areas of concentration of stone items marked as clusters and also areas with scattered findings. Most of the artifacts are located on the flat surface of the second terrace (Fig. 2). Artifacts were found across the whole depth of the cultural layer $(20 \mathrm{~cm})$, and at every level there were interrelated and homogeneous stone pieces. Therefore, the difference in the depths of the objects ${ }^{1}$ found in the clusters was not taken into account.The clusters were identified as such based on 2 criteria: 1) their spatial isolation and 2) homogeneity of findings. The homogeneity of the artifacts was demonstrated by the similarity of raw materials and technological contexts of stone pieces, their morphological closeness, the connection of objects proved by refitting method, as well as the typological unity of the accompanying ceramic tableware. To identify the boundaries of the cluster we took into account the findings from the surrounding area, in some cases, the boundaries were determined along the areas of distribution of objects of a different cultural and chronological shape.

The next point to consider was the possible relocation of certain artifacts, which is proved indirectly by the low density of findings in these clusters and their remoteness from each other. Other factors which hindered the identification of cluster boundaries were the overlapping of materials attributed to different time periods and cases of gradual peripheral decrease in the concentration of findings in the clusters represented by heterogeneous complexes of stone products without any pottery. These circumstances required a critical assessment of the materials and limited the scope of a more detailed analysis of the internal structure and functional interpretation of the clusters.

The stone industry from the Itomiura site (excavation No. 2) consists of 1,346 objects ${ }^{2}$ (Table), most of which $(91.8 \%)$ made clusters.

\footnotetext{
1 The most probable reason for this is the vertical transfer of findings, which is typical for light soils (Gurina, 1990).

2 Not taking into account abrasive tools, pebbles and other raw material units with little or no traces of treatment. These subjects require special microwear studies.
}

The raw material base of the stone industry is comprised by two groups of rocks ${ }^{3}$. The first group includes lithified sedimentary rocks ranging from fine-grained to latently crystalline. They accounted for $42.5 \%$ of the collection. Artifacts are either covered with thin (up to $1 \mathrm{~mm}$ ) aleurite-pelitic crust or their surface has lighter shades, which complicates their more accurate diagnosis. A number of samples underwent silicification and, presumably, metamorphic changes (hornstone). As a rule, their colour is homogeneous, in grey and pale yellow tones, reddish-brown or purple-burgundy. The second group is represented by flints and siliceous rocks of different composition. It has slightly more objects $-53.8 \%$. Here units are mainly colourful, have spots and gradient change of colour; these stone items are coloured in various grey, yellow-red and brown shades, forming a plenty of types. The absolute majority of the group $(88.7 \%)$ consists of objects of cracked, predominantly chalcedony rock with miscellaneous grey-yellow colouring. Apart from the groups, there were found only a few dark coloured fine-grained effusives $(1.1 \%)$ and secondary quartzites $(0.4 \%)$. And a part of the collection (2.2\%) could not be identified as belonging to any particular group.

Cluster $\mathbf{1}$ is located in the south-eastern part of the excavation, on the slightly sloping transition to the second terrace. Dimensions of the cluster are $12 \times 14 \mathrm{~m}$. Most of the findings are concentrated in the south-western part of the excavation.

There are 59 pieces of stone found here, among which there are predominantly non-standardized, mainly small ( $\leq 25 \mathrm{~mm}$ long) knapping products (53 pcs), including a medial blade fragment and a proximal shatter of a semi- ridge blade. Of the two fragments found in the cluster, one microcore (?) with negatives of wide sub-parallel lamellar flakes taken from the front is conjoined (Fig. 2, 1).

The tools (4 pcs) include a fragment of the ground adze (a part adjacent to the blade)

\footnotetext{
Macroscopic definitions of reference samples were made by Tatyana E. Iurieva, the Head of the Department of Inventory and Storage in the Geological Collection Fund of Krasnoyarsk Branch of the Federal Budgetary Institution "Territorial Fund of Geological Information of Siberian Federal District".
} 
Dmitry A. Gurulev, Liliya A. Maksimovich... Lithic Industry of the Itomiura Site in the Lower Angara Region...

Table. Typological composition of the site Itomiura lithic industry (excavation No. 2)

\begin{tabular}{|c|c|c|c|c|c|c|c|c|c|c|c|c|c|c|c|c|}
\hline & \multicolumn{2}{|c|}{ Items* / cluster number } & 1 & 2 & 3 & 4 & 5 & 6 & 7 & 8 & 9 & 10 & 11 & 12 & SF & Total \\
\hline \multirow{4}{*}{ 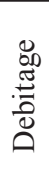 } & \multicolumn{2}{|c|}{ Flakes } & 31 & 45 & 127 & 328 & 75 & 12 & 129 & 82 & 32 & 4 & 3 & 2 & 61 & 931 \\
\hline & \multicolumn{2}{|l|}{ Chips } & 20 & 12 & 25 & 152 & 2 & - & 17 & 19 & 9 & 7 & 2 & - & 6 & 271 \\
\hline & \multicolumn{2}{|c|}{ Blades } & 1 & - & - & - & - & - & - & - & - & - & - & - & 2 & 3 \\
\hline & \multicolumn{2}{|c|}{ Core trimming elements } & 1 & - & 3 & - & 1 & - & - & - & - & - & 2 & - & 3 & 10 \\
\hline \multirow{8}{*}{$\begin{array}{l}\overrightarrow{0} \\
\infty \\
0 \\
0 \\
0\end{array}$} & \multirow{2}{*}{ 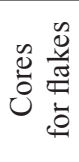 } & $\begin{array}{l}\text { Single-front } \\
\text { double-platform }\end{array}$ & - & & - & - & - & - & - & - & - & 2 & - & - & - & 2 \\
\hline & & $\begin{array}{l}\text { Single-front } \\
\text { single-platform }\end{array}$ & - & - & - & - & - & - & - & - & - & 1 & - & - & 2 & 3 \\
\hline & \multirow{5}{*}{ 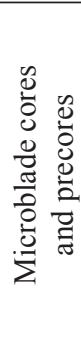 } & $\begin{array}{l}\text { Prismatic } \\
\text { single-front }\end{array}$ & 1 & 1 & - & - & - & 1 & - & - & - & 1 & 1 & - & 2 & 7 \\
\hline & & $\begin{array}{l}\text { Double-front similar } \\
\text { to wedge-shaped }\end{array}$ & - & - & - & - & - & 3 & - & - & - & - & - & - & - & 3 \\
\hline & & Wedge-shaped & - & - & 2 & - & - & - & - & - & - & - & - & - & 1 & 3 \\
\hline & & $\begin{array}{l}\text { Pseudo-wedge- } \\
\text { shaped }\end{array}$ & - & - & - & - & - & 1 & - & - & - & - & - & - & & 1 \\
\hline & & Edge-faceted & - & 2 & - & - & - & - & - & 1 & - & - & - & - & 1 & 4 \\
\hline & \multicolumn{2}{|c|}{ Core-shaped items } & - & - & - & 1 & 1 & - & - & - & - & - & - & - & 3 & 5 \\
\hline \multirow{8}{*}{$\begin{array}{l}\overrightarrow{0} \\
\infty \\
0 \\
0 \\
0\end{array}$} & \multicolumn{2}{|c|}{ Axes \& adzes } & 2 & 1 & - & - & 7 & - & - & 1 & - & - & - & 1 & 10 & 22 \\
\hline & \multicolumn{2}{|c|}{ End-scrapers } & 1 & - & - & - & - & - & - & - & - & - & - & - & 4 & 5 \\
\hline & \multicolumn{2}{|c|}{ Knives } & - & - & - & - & - & - & - & 1 & - & - & - & - & - & 1 \\
\hline & \multicolumn{2}{|c|}{ Arrowheads } & - & - & - & - & 5 & - & - & - & - & - & - & - & - & 5 \\
\hline & \multicolumn{2}{|c|}{ Bifaces \& bifacial items } & - & 1 & 1 & - & 2 & - & 1 & 4 & 1 & - & - & 1 & 3 & 14 \\
\hline & \multicolumn{2}{|c|}{ Chisel-like tools } & - & 1 & - & - & - & - & - & - & - & - & - & - & - & 1 \\
\hline & \multicolumn{2}{|c|}{ Thinned preforms } & - & - & - & - & - & - & - & 1 & 3 & - & - & 1 & - & 5 \\
\hline & \multicolumn{2}{|c|}{ Flake tools } & 1 & 2 & 3 & 3 & 4 & 1 & 2 & 2 & 5 & 5 & 1 & 4 & 6 & 39 \\
\hline \multicolumn{3}{|c|}{ Unidentifiable tools \& items } & 1 & - & - & - & 2 & - & 2 & - & - & - & - & - & 6 & 11 \\
\hline \multicolumn{3}{|c|}{ Total } & 59 & 65 & 161 & 484 & 99 & 18 & 151 & 111 & 50 & 20 & 9 & 9 & 110 & 1346 \\
\hline
\end{tabular}

* Including both whole and fragmented, as well as unfinished items.

with sub-parallel flaking scars on the back (there was a conjoined flake found outside the cluster, 9 m southwest of it) (Fig. 2, 2); conjoined unfinished irregularly shaped chopping tool with traces of microflaking and rounding of the rib (Fig. 2, 3); oblique end-scraper on a massive flake (Fig. 2, 4); and a stone chip with traces of grinding on one of its facets and smoothed edge of the rib. The unidentifiable itemis the poorly rolled thorned tool on the chip.

The assemblage contains stone pieces made of various raw materials. There are debitage products (13 pcs) of burgundy sedimenta- ry rocks that concentrated in the northern part of the cluster.

Cluster 2 is located in the south-eastern part of the excavation, on the slightly sloping transition to the second terrace. The size of the cluster is $13 \times 9 \mathrm{~m}$. In the north-eastern sector there is an thin oval-shaped spot of heat-treated soil with the dimensions of $1.1 \times 1.4 \mathrm{~m}$. Most of the findings are concentrated to the west of the fireplace.

There are 65 pieces of stone in the collection. The most numerous (57 pcs) are non-standardized, mostly small ( $\leq 25 \mathrm{~mm}$ long) debitage products. Collection of cores includes 
3 items - prismatic microcore with irregular flaking surface and acute angle, flat platform, as well as two end microcores on chips with straight flat platforms (Fig. 2, 5, 6).

The tool set ( $5 \mathrm{pcs}$ ) is comprised of a small rectangular-like bifacial item (unfinished arrowhead?) (Fig. 2, 7); a two-blade chisel-like tool on a flake (Fig. 2, 8); a chopping tool without a blade part (Fig. 2, 9); and a large flake and chip with traces of retouch or edge damage.

Stone pieces are heterogeneous in terms of raw materials.

Cluster 3 is located in the south-western part of the excavation, on the on the edge of the cape-shaped protrusion of the second terrace. The size of the cluster is $7 \times 6 \mathrm{~m}$. The concentration of findings is relatively dense, the maximum concentration is in the southern sector with a small part of the objects found in 1-3 $\mathrm{m}$ from this part. Inside the cluster there was found a series of conjoined objects.

There are 161 stone items found here. The predominant products are of debitage (155 items), most of which can be presumably attributed as biface trimming flakes (Apel, 2001: 154), a medial-distal fragment of a microblade with longitudinally-transversal scars on the dorsal surface and two ski spalls. The cores are represented by the same type of wedge-shaped core outline (Fig. 2, 10) and used core (Fig. 2, 11) on elongated bifacial preforms. These pieces are conjoined with ski spalls.

Among the tools (4 pcs) there was found a small fragment of bifacial item and expedient tools - two fragments of large blades and a flake with traces of retouch or edge damage.

The main part of the items (147 pcs) is made up of sedimentary rock with pale yellow crust, including cores, core trimming flakes, tools and the majority of the debitage (138 pcs).

Cluster 4 is located in the south-eastern part of the excavation, on the brow part of the second terrace. The size of the cluster is $7 \times 6 \mathrm{~m}$. The majority of the stone pieces are concentrated in three isolated spots scattered in different sectors of the cluster.

The assemblage include 484 stone items with prevailing (480 pcs) of non-standardized knapping products. There were also found a bifacial treated irregular discoidal core-shaped product and three flat chips with marginal retouch.

The absolute majority of debitage products (477 pcs) and core-shaped item are made of unevenly coloured grey-yellow chalcedony rock. Several flakes ( $7 \mathrm{pcs}$ ) from a similar rock were found $17 \mathrm{~m}$ east to the cluster.

Cluster 5 is located in the western part of the excavation, on the surface of the second terrace. The size of the cluster is $29 \times 18 \mathrm{~m}$. Stone pieces were scattered over the entire area with a slight predominance in the eastern sector. Single refit links indicate that objects inside the cluster spread across the area up to $12 \mathrm{~m}$ wide.

There were found 99 pieces made of stone. The majority of them are debitage (78 pcs), including flakes (about $22 \mathrm{pcs}$ ) of production of quadrilateral axes and adzes (Apel, 2001: 154) and flakes with dorsal residues ground areas (5 pcs), as well as a half-cortical bladelet. There was also a core-shaped product with multidirectional irregular treatment along two facets.

The tool set (18 pcs) is represented by chopping tools ( 7 pcs), arrowheads (5 pcs), expedient flake tools with traces of retouch or edge damage (4 pcs), as well as fragments of unidentifiable bifacial items $(2 \mathrm{pcs})$. In the group of chopping tools there are unfinished products ( 3 pcs) and shaped tools ( 2 pcs), as well as tool fragments $(2 \mathrm{pcs})$. All the pieces have rectangular and trapezoidal silhouette with rectangular cross-section. Unfinished items show signs of irregular quadrilateral treatment and, in one case, partial grinding (Fig. 2, 12-14). One of the base fragments was reshaped into a core (?) (Fig. 2, 15). Shaped ground tools have large use retouch scars on the working edges (Fig. 2, 16-17). Arrowheads are represented by a triangular-like item with a slightly concave base (Fig. 2, 18), two unfinished products of leaf shape (Fig. 2, 19), and two fragments of points. Unidentifiable products include a fragment of platy unit of raw material with scars of episodic treatment and an amorphous shape chip with irregular retouch of three conjugate planes.

Most of the items of the complex (80 pcs), including the overwhelming part of the debitage (64 pcs), chopping and expedient flake tools, unfinished products and fragments of arrowheads, as well as the unidentifiable tabular 
unit, are made of the same type of sedimentary rocks with grey-pale crust.

Cluster $\mathbf{6}$ is located in the western part of the excavation, on the brow part of the second terrace. The size of the cluster is $5 \times 6 \mathrm{~m}$. The distribution of the findings is relatively even, with individual objects radially separated from the main area of concentration by 1-3 $\mathrm{m}$.

The collection is made up of a total of 18 stone objects, including 12 knapping products, five microcores and a medial fragment of blade-like flake with retouched edge. The following products are of particular interest: pseudo-wedge-shaped core on a massive flake (Fig. 2, 20), prismatic single-front core (Fig. 2, 21) and three double-front two-platform cores, similar in shape to the wedge-shaped items (Fig. 2, 22-24). All cores are characterized by acute angle, flat platforms and irregular flaking surfaces.

Cores were made of similar types of purple-burgundy rocks. The same raw materials are presented in four flakes, including two blade-like. The rest of the debitage is made of sedimentary rocks with grey crust.

Cluster 7 is located in the central part of the excavation, on the surface of the second terrace. It is a $10 \times 5 \mathrm{~m}$. In the central sector there are two areas of concentration of findings, separated by a distance of $2 \mathrm{~m}$ from each other.

The cluster included 151 stone products. The main part is made up of products of debitage (146 pcs), among which small flakes (length $\leq 25 \mathrm{~mm}$ ) prevail. Most of the debitage is believed to be related to the final treatment of bifaces and thinned preforms (see: Gurulev, Kharevich, 2016).

There were also found a trapezoidal biface with a convex wide blade, made, presumably, on the thinned preform (Fig. 3, 1); two flakes with retouch or edge damage and two fragments of undefined items. One of them is conjoined with the flakes found $7 \mathrm{~m}$ away from it.

With the exception of biface and two flakes, the raw materials for stone pieces was one unit of purple-burgundy banded sedimentary rock. Asymmetrical-triangular biface (Fig. 3, 2) and three flakes of similar raw materials, which may have been part of the same complex, were found $15 \mathrm{~m}$ east to the cluster.
Cluster 8 is located in the central part of the excavation, on the surface of the second terrace. The size of the cluster is $22 \times 9 \mathrm{~m}$. The findings are distributed relatively evenly over the area, with a slight increase in concentration in the central sector.

A total of 111 pieces of stone were found in the cluster, most of which (101 items) are non-standardized knapping products, e.g., an end microcore with flat platform on a bifacially treated large lamellar flake (Fig. 3, 3). The core is conjoined of two fragments. Bifacial knapping flake is also conjoined to it, as it had been chipped off before the object underwent fragmentation. The objects were found in $1.5 \mathrm{~m}$ from each other.

The tools $(9$ pcs) include four bifacial items, a ground rectangular axe with a square cross-cut section and a straight blade (Fig. 3, 4), as well as two flakes with traces of retouching or edge damage. From two fragments (one of which was found in cluster 7) refit up a massive item with an irregular uni-facial thinning treatment (Fig. 3, 5). The complex consists of a knife with a shape close to semi-lunar and a distinct handle part offset relatively to the axis of the tool (Fig. 3, 6), and four irregularly treated fragments of unfinished (?) bifacial items (Fig. 3, 7-9).

The absolute majority of the objects in the cluster, including the most part of the debitage (96 items), one of the fragments of bifacially treated products and flake with retouch, are made of unevenly colored grey-yellow, even reddish chalcedony rock, similar in appearance to the raw material from cluster 4 .

Cluster 9 is located in the central part of the excavation, on the surface of the second terrace. The size of the cluster is $7 \times 5 \mathrm{~m}$. Most of the objects are concentrated in the southern sector, with some findings removed up to $4 \mathrm{~m}$ to the north.

The collection includes 50 items made of stone, the majority of which are non-standardized knapping products (41 pcs). Some objects also found here include a fragment of irregularly treated bifacial item (Fig. 3, 10), three small fragments of pieces with bifacial thinning treatment, as well as five massive flakes and chips with retouch or edge damage. 


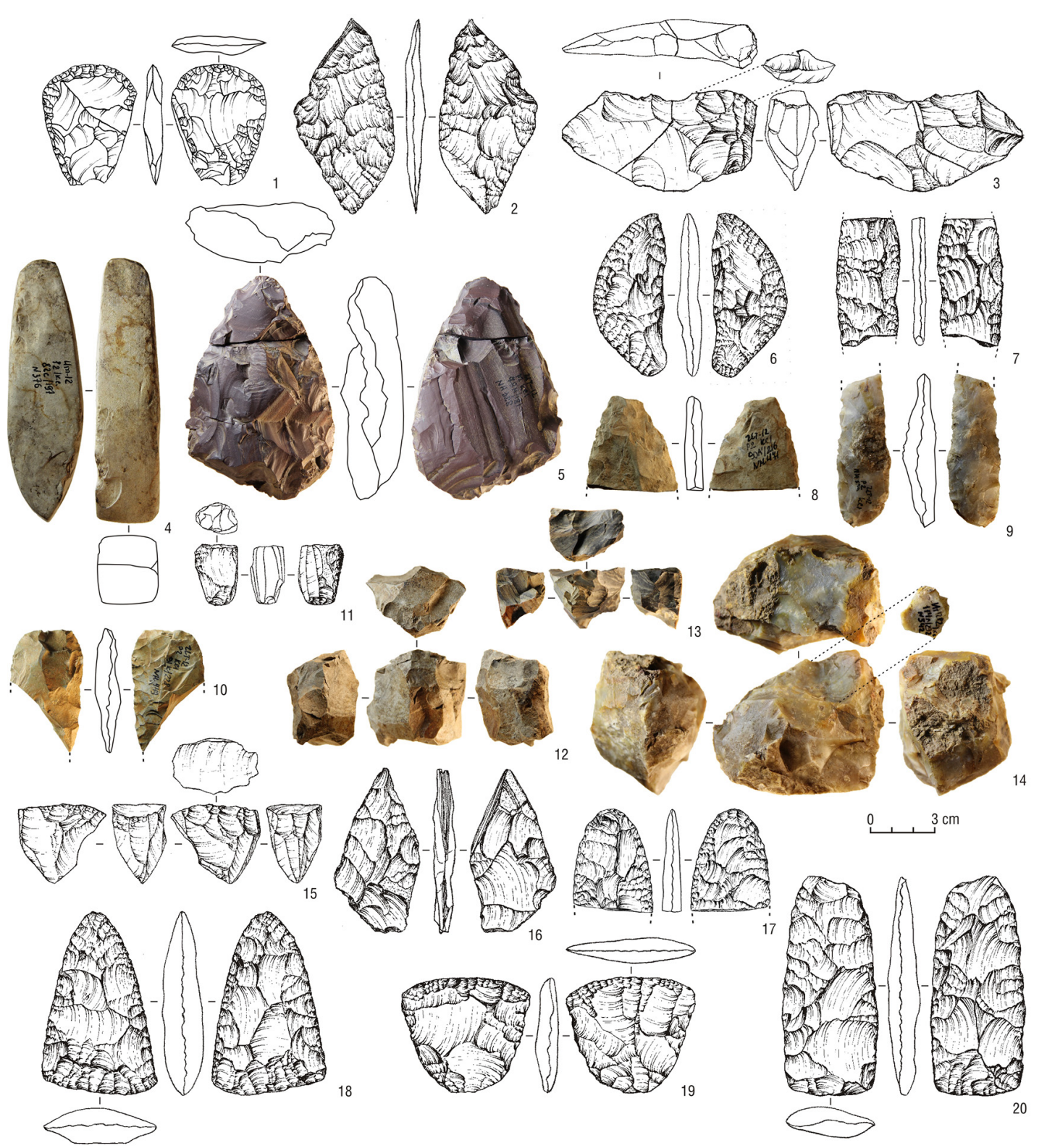

Fig. 3. Lithic industry of the site Itomiura (excavation No. 2): 1 - cluster 7; 2, 18-20 - scattered finds; 3-9 - cluster 8; 10 - cluster 9; 11-14 - cluster 10; 15 - cluster 11; 16, 17 - cluster 12. 1, 2, 19 - bifaces and bifacial items; 3, 11, 15 - microcores; 4, 18, 20 - chopping tools; 5, 16 - thinned preforms; 6 -knive; 7-10, 17 - bifaces and bifacial item fragments; $12-14$ - cores for flakes

The items (34 pcs) made of purple-burgundy banded sedimentary rock, similar to the items from cluster 7 , are predominantly. This raw material form the most part of the debitage ( $27 \mathrm{pcs})$, thinned preforms and four flake tools. Another sedimentary rock with a homogeneous light grey crust was used for debitage (11 pcs) and a flake with retouch.

Cluster $\mathbf{1 0}$ is located in the northern part of the excavation, on the brow part of the third terrace. The size of the cluster is $40 \times 11 \mathrm{~m}$. There are three areas of scattered stone products location, which are accompanied by con- 
centrations of pottery fragments. The most remote, north-western one, is connected with the remains of a large oval-shaped fireplace with dimensions of $1.4 \times 1.6 \mathrm{~m}$.

There are 20 pieces of stone in this collection. The debitage $(11 \mathrm{pcs})$ are represented by non-standardized products. Obtaining blanks technology is represented by four different cores. One prismatic microcore is close to the wedge-shaped one, it has one platform with a narrow flaking surface (Fig. 3, 11), moreover, there are one single-front core for flakes with one platform (Fig. 3, 12) and two single-front flake cores with two platforms (Fig. 3, 13, 14).

The tool set includes a two-piece (conjoined) point on the flake and four expedient tools with traces of retouch or edge damage on the flakes and the blade. One of the retouched flakes is conjoined to the front of one of the flake cores, the distance between these objects is as long as $31 \mathrm{~m}$.

The assemblage constitutes a heterogeneous complex of raw materials.

Cluster 11 is located in the north-eastern part of the excavation, on a cape-shaped ascent of the third terrace. The size of the cluster is $11 \times 5 \mathrm{~m}$. Few scattered findings of stone items were found mainly in its western sector.

Of the 9 pieces found in the cluster, seven are products of debitage, including two rejuvenation microcores tablets, a prismatic microcore with one flat platform and irregular circular front (Fig. 3, 15), as well as a flake with retouch.

Five products, including microcore, a core tab, a flake tool, as well as two more flakes, are made of the same type of spotted (breccia) light grey siliceous rock.

Cluster 12 is located at the north-eastern edge of the excavation, in the joint part of the third terrace. The size of the cluster is $7 \times 8 \mathrm{~m}$.

Of the 9 scattered stone items, seven are tools and two are flakes. The tools include a partially ground chopping tool (?) on a large lamellar flake with a broken blade part; a bifacial thinned preform (Fig. 3, 16); a fragment of the terminal part of the biface (Fig. 3, 17); and four different expedient tools on the chip and flakes with traces of retouch or edge damage. The items are made of different raw materials.
Outside of the clusters there were found 110 stone items represented by a variety of knapping products $(72 \mathrm{pcs})$, distinct cores of different types (9 pcs), tools ( 23 pcs) and unidentifiable pieces (6 pcs). It should be noted that there is a set of choping and bifacial tools near the western boundary of the excavation, to the north-west of cluster 5 (Fig. 3, 18-20). This set is made of homogeneous raw materials of sedimentary origin with pale yellow crust. Also there is an increased concentration of different finds in the southern part of the excavation. In the northern part of the excavation, on the surface of the third terrace, there was found a large adze with "ears", conjoined of four fragments, separated from each other by a distance of up to $15 \mathrm{~m}$.

\section{Discussion}

Cluster materials attest of diverse episodic habitats and various types of economic and production activities. According to the composition of the stone items, the clusters can be divided into two groups, differing in aim. The first group consists of clusters 1 and 2 which included the tools and falkes of small sizes with different morphology and from different raw materials. The appearance of these areas is likely to be more related to the use of stone tools and their rejuvenation.

There are more numerous areas with multiple products of debitage, different unfinished tools and waste cores. This group has been singled out to give priority to the knapping activities associated with the manufacture of tools and blanks. This group may include materials from clusters of 3-9, different in their specifics. In particular, there can be distinguished complexes of clusters 3 and 6 demonstrating microblade production. Clusters 4, 7 and 9 can be interpreted as areas for the manufacture of individual items. So, materials of cluster 4 are presented to the greater extent by products of knapping of unit (-s?) of chalcedony rock, chipped, probably, from the core-like piece also found here. The morphology of the debitage signalises selective knapping associated with the low quality (cracking) of the raw material. The purpose of the treatment, in this case, is difficult to determine. Similar industries, in the 
neighbouring clusters 7 and 9, are mainly represented by the waste products of thinned preform and possibly bifaces knapping. The pieces made of at least two platy unit of the same type of purple-brown sedimentary rock. The materials from cluster 5 present a mono-material complex of unfinished and formed axes and adzes, workpieces of arrowheads. A series of morphologically homogeneous debitage was created here during the manufacture and, to a lesser degree, during the reshaping of chopping tools. In cluster 8 there is a joint presence of waste productsof one unit of chalcedony rock knapping, a set of different tools, bifacial items and used microcore. In addition to the above characterized components demonstrating internal unity in all clusters of the group, there was discovered a small share of debitage from other raw materials and individual, non-serial tools. The above may be related to the versatility of activities at the areas, as well as the result of mixing of materials of complexes belonging to different time periods.

Interpretation of clusters 10-12, which hosted few non-serial findings, is rather difficult. The joint location of items may be associated with random events belonging to different time periods or attest to a separate, short-term episode of habitat. The latter interpretation is most likely to be the case for cluster 10 , which has a relatively clear spatial structure that includes the fireplace and concentration zones of pottery.

The cultural identification and grouping of the clusters can be assumed on the basis of the joint occurrence of fragments of ceramic vessels with stone items.

The cultural and chronological complex of the Neolithic is connected with net-impressed pottery. The outer surface of these vessels is covered with "net" imprints and ornamented lines and belts of holes under the rim. At the Itomiura site, such pottery found in clusters 1 , 2 in particular. It were preliminarily attributed to the Late Neolithic period (fourth - the first half of the third millennium BC) (Senotrusova, Mandryka, 2018). Located in close proximity to each other, the clusters form one site on the slope of the second terrace in the south-eastern sector of the excavated area.
The cultural and chronological complex of the Bronze Age is the most representative. Its presence is determined by the so-called "pearlribbed" pottery, i.e. fragments of vessels, the outer surface of which is covered with ribbed imprints, and the ornament includes a belt of "pearls" under the rim (Mandryka and Senotrusova, 2014). The ceramic tableware of this type in the Itomiura site is typologically uniform, which, on the basis of the obtained ${ }^{14} \mathrm{C}$ dates $^{4}$, allows us to date it back to the second millennium BC.

The findings from clusters 6 and 7 can be most reliably included into this complex. In clusters 5 and 8, pottery of the early Iron Age and, to a lesser extent, Neolithic was also found. However, the characteristics of the assemblages suggest that they most likely belong to the Bronze Age. This complex also includes materials from cluster 9, which did not contain pottery. The reasons for this are the unity of the industry with the materials of cluster 7 and, indirectly, their close location. It is also likely that the materials of cluster 12 , which is similar to other products of the complex, should be attributed to the Bronze Age.

In cluster 10 were found fragments of several vessels attributed to the Tzepan (Mandryka, Senotrusova, 2014: 71) archaeological culture of the Early Iron Age (the $8^{\text {th }}-$ the $2^{\text {nd }}$ centuries BC). In particular, the vessels from the cluster can be compared with the Vzvoz type of pottery (Leont'ev, German, 2015). Thus, the materials of the cluster indicate the use of stone pieces at this time, in particular expedient flake tools, for the manufacture of which simple forms of cores were used.

Cultural identification of materials from clusters 3, 4 and 11 that did not contain pottery is challenging. Materials from cluster 3 demonstrate the Yubetsu-like technological model of flaking of bifacial elongated wedge-shaped microcores which platforms are treated with ski spalls. Completely or partially analogous models are represented in a number of different cultures of the Late-Final Paleolithic (Late

\footnotetext{
4 There were obtained two dates corresponding to the middle of the $17^{\text {th }}$ - middle of the $15^{\text {th }}$ centuries $\mathrm{BC}$ and the middle of the $15^{\text {th }}$ - the end of the $13^{\text {th }}$ centuries BC, respectively (Mandryka, Senotrusova, 2014: 77).
} 
Pleistocene) and, to a lesser extent, in the Mesolithic Periods (Early Holocene) of the south of Middle Siberia (Lynsha, 1980; Generalov, 2001; etc) but not widespread. The authors have not come across such a technological model in the archaeological complexes of the Neolithic and Bronze Age in the Lower Angara and adjacent regions. Taking into account the compression of the cultural layer of the site it is possible to assume both the earlier age of the cluster items and, on the other hand, the possibility of an occasional manifestation of such a technological model in the Neolithic and Bronze Age cultures.

\section{Conclusion}

On the basis of the analysis results of industries of different cultural and chronological complexes, which were singled out in the Itomiura site, it is possible to tentatively indicate a number of their characteristic features.

The Neolithic complex associated with net-impressed pottery is marked by a greater number and variety of flints as raw materials. For the industry of the Bronze Age linked with "pearl-ribbed" pottery, the most typical items are made of purple-burgundy sedimentary rocks. Both complexes are characterised to a greater or lesser extent by the use of sedimentary rocks with homogeneous grey-pale yellow crust and cracked chalcedony rock of grey-yellow colour. The latter is relatively widespread, which combined with its low quality, may indicate their origin from locally readily available sources.

\section{References}

Apel, J. (2001). Daggers knowledge and power: The social aspects of flint dagger technology in Scandinavia (2350-1500 cal BC). Uppsala, 365 p.

Berdnikova, N.E., Rogovskoi, E.O., Berdnikov, I.M., Lipnina, E.A., Lokhov, D.N., Dudarek, S.P., Sokolova, N.B., Timoshchenko, A.A., Popov, A.A., Kharlamova, N.V. (2014). Stoianka imeni Generalova (r. Chuna). Rezul'taty okhranno-spasatel'nykh rabot 2013 goda [Generalov Site (the Chuna River). Results of Rescue Excavations in 2013]. In Izvestiia Irkutskogo gosudarstvennogo universiteta [Bulletin of the Irkutsk State University], 7, 150-191.

Generalov, A.G. (2001). Pozdnii paleolit - rannii mezolit Kansko-Eniseiskogo regiona [Late Paleolithic - Early Mesolithic periods in Kansk-Yeniseysk region]. Abstract of the Thesis of the Candidate of Historical Sciences. Irkutsk, 42 p.

Gurina, N.N. (1990). Osnovnye metodicheskie priemy raskopok mezoliticheskikh i neoliticheskikh poselenii v rykhlykh otlozheniiakh [Main methods of excavation of the Mesolithic and Neolithic sites in 
loose sediments]. In Polevaia arkheologiia mezolita - neolita [Field archeology of the Mesolithic - Neolithic periods], 7-23.

Gurulev, D.A., Kharevich, V.M. (2016). Zagotovki s obbivkoi utoncheniia v kamennykh industriiakh golotsena Severnogo Priangar'ia [Billets (thinned performs) from Holocene stone industries of the Northern Angara region]. In Materialy V Mezhdunarodnoi nauchnoi konferentsii "Ekologiia drevnikh i traditsionny$k$ obshchestv" [Proceedings of V International Scientific Conference "Ecology of ancient and traditional societies"], 34-38. Tyumen.

Leont'ev, S.N., German, P.V. (2015). Keramicheskii kompleks pervogo kul'turnogo gorizonta stoianki Vzvoz, punkt 2 (Severnoe Priangar'e) [Pottery complex of the first cultural layer of the site Vzvoz, point 2 (Northern Angara region)]. In Drevnosti Prieniseiskoi Sibiri [Prehistory of the Yenisey Siberia], 7, 87-106.

Lynsha, V.A. (1980). Mezolit iuga Srednei Sibiri [Mesolithic findings of the south of Central Siberia]. Abstract of the Thesis of the Candidate of Historical Sciences. Leningrad, $16 \mathrm{p}$.

Mandryka, P.V. (2003). Ispol'zovanie i obrabotkakamnia v zheleznom veke po materialam iuzhnoi taigi Srednego Eniseia [Using and treatment of stones in the Iron Age based on the materials of the southern taiga of the Middle Yenisei region]. In Kul'tura Sibiri i sopredel'nykh territorii v proshlom i nastoiashchem [The culture of Siberia and adjacent areas in the past and present], 207-208.

Mandryka, P.V. (2018). K metodike opredeleniia granits poselencheskogo kul'turnogo sloia na beregovykh terrasakh (na primere ansamblia arkheologicheskikh pamiatnikov Shivera Prospikhino v Nizhnem Priangar'e) [On the methods of determining the boundaries of cultural layer for a settlement on coastal terraces (the case of the archaeological site ensemble Prospikhino in Shivera village in the Lower Angara region)]. In Drevnosti Prieniseiskoi Sibiri [Prehistory of the Yenisey Siberia], 9, 51-61.

Mandryka, P.V., Senotrusova, P. O. (2014). Kul'turno-khronologicheskie kompleksy paleometalla i srednevekov'ia stoianki Itomiura v Severnom Priangar'e [Cultural and chronological complexes of the Paleo-metal and the Middle Ages of the site Itomiura in the Northern Angara region]. In Izvestiia Irkutskogo gosudarstvennogo universiteta [Bulletin of the Irkutsk State University], 8, 63-81.

Senotrusova, P.O., Mandryka, P.V. (2018). Neoliticheskaia keramika stoianki Itomiura [Neolithic pottery of the Itomiura site]. In Evraziia v kainozoe. Stratigrafia, paleoekologiia, kul'tury [Eurasia in the Cenozoic Era. Stratigraphy, paleoecology, culture], 7, 258-265.

Vybornov, A.V., Tsybankov, A.A., \& Makulov, V.I. (2015). Arkheologicheskie ob'ekty na beregakh Angary ot reki Chadobets do poselka Boguchany: obzor i zakonomernosti [Archaeological sites on the banks of the Angara River from the Chadobets River to Boguchany village: overview and patterns]. In Arkheologiia, etnografiia i antropologiia Evrazii [Archaeology, Ethnology and Anthropology of Eurasia], 4 (43), 46-53. DOI: 10.17746/1563-0102.2015.43.4.046-053. 


\title{
Каменная индустрия комплексов неолита \\ и бронзового века стоянки Итомиура \\ в Нижнем Приангарье: \\ планиграфия и ключевые характеристики
}

\author{
Д.А. Гурулёв, Л.А. Максимович, \\ П.О. Сенотрусова, П.В. Мандрыка \\ Сибирский федеральньй университет \\ Российская Федерачия, Красноярск
}

\begin{abstract}
Аннотация. В работе представлены результаты анализа каменной индустрии стоянки Итомиура, расположенной в Нижнем Приангарье. На основании пространственного распределения находок в культурном слое памятника выделено 12 участков концентрации изделий из камня (скоплений). Выделенные площадки различаются по составу и видам происходившей на них хозяйственно-производственной деятельности. Преобладают площадки, включающие большое количество продуктов расщепления, незаконченные изделия и сработанные нуклеусы. Также отмечены площадки, формирование которых, вероятно, в большей степени связано с использованием каменных орудий и их подправкой. Совместное залегание каменных изделий с фрагментами керамической посуды позволяет рассматривать их как отдельные культурно-хронологические комплексы. Наиболее выразительны комплексы с «сетчатой» керамикой, предварительно датированной поздним - финальным неолитом (IV - перв. пол. III тыс. до н.э.), и с «жемчужно-рубчатой» посудой бронзового века (II тыс. до н.э.). Для неолитического комплекса характерно использование разнообразного кремнистого сырья. В комплексе бронзового века отмечено широкое использование фиолетово-бордовых осадочных пород, специфику индустрии также формирует серия бифасиальных форм и изделий с оббивкой утончения. Для каменных индустрий обоих комплексов характерны разнообразные неформальные орудия и продукты микропластинчатого производства, представленные различными призматическими и торцовыми нуклеусами. Полученные данные, при их корреляции с материалами других памятников, актуальны для дальнейшего изучения каменных индустрий голоцена Нижнего Приангарья и разработки концепции региональной палеокультурной динамики.
\end{abstract}

Ключевые слова: Средняя Сибирь, Нижнее Приангарье, неолит, бронзовый век, каменная индустрия, каменное сырье, планиграфия, сетчатая керамика, жемчужно-рубчатая керамика.

Исследование выполнено при финансовой поддержке Российского фонда фундаментальных исследований, Правительства Красноярского края, Красноярского краевого фонда поддержки научной и научно-технической деятельности в рамках научного проекта № 16-11-24005.

Научная специальность: 07.00.00 — исторические науки и археология. 